\section{Do the Clinical Effects of Enamel Matrix Derivatives in Infrabony Defects Decrease Overtime? A Systematic Review and Meta-Analysis}

Fabricio Batistin Zanatta ${ }^{1}$, Fernanda Goulart de Souza ${ }^{2}$, Tatiana Militz Perrone Pinto ${ }^{3}$, Raquel Pippi Antoniazzi ${ }^{3}$, Cassiano Kuchenbecker Rösing ${ }^{4}$

\author{
'Department of Stomatology, \\ UFSM - Federal University of \\ Santa Maria, RS, Brazil \\ ${ }^{2}$ UNINGÁ - Ingá University, \\ Santa Maria, RS, Brazil \\ ${ }^{3}$ UNIFRA - Franciscan College \\ Center, Santa Maria, RS, Brazil \\ ${ }^{4}$ Department of Periodontology, \\ UFRGS - Federal University of Rio \\ Grande do Sul, Porto Alegre, RS, Brazil
}

Correspondence: Prof. Dr. Fabricio B. Zanatta, Rua Tiradentes, 76/801, 97050-730 Santa Maria, RS, Brasil. Tel.: +55-55-3307-8026. e-mail fabriciobzanatta@gmail.com

Key Words: dental enamel proteins, clinical trial, guided tissue regeneration, periodontal.

\section{Introduction}

Destructive periodontal diseases are of multifactorial nature, with the subgingival biofilm being the main etiologic agent (1). From this standpoint, the core approach for its therapy is to disorganize and disperse biofilm by mechanical means and, in some situations, with adjunct chemical agents (2). Moreover, as additional therapeutic approach for affected sites with periodontal tissue destruction, there is the possibility of using regenerative techniques that aim at periodontal reconstruction, forming tissues that were previously lost due to disease progression (2-5).

Periodontal regeneration presupposes formation of periodontal ligament with collagen fibers inserted in new cementum and new alveolar bone (6-8). With this purpose, diverse regenerative procedures have been developed and are available, such as guided tissue regeneration (GTR), associated or not with bone grafts or alloplastic materials (3,9-11). At present, advancements in molecular biology studies emphasized the importance of extracellular matrices in periodontal regeneration. Enamel matrix derivative proteins (EMDP), especially amelogenin, appear to play an important role in cementogenesis $(12,13)$. Thus, in an endeavor to provide mimicking of what occurs during root development, an enamel matrix derivative of porcine origin has been used in an attempt to regenerate previously lost periodontal structures (13-17).
Bosshardt (18), in a systematic search of the literature, described the in vitro evidence of the biologic properties of EMDPs, such as stimulation of chemotaxis, cell proliferation, adhesion and survival, increase in the expression of growth factors, cytokines, extracellular matrix constituents and molecules involved in the regulation of bone formation. One of the indications for the use of EMDPs is for the management of infrabony periodontal defects (IPD). The use of EMDP in such defects has been histologically evaluated in animals $(19,20)$ and in humans $(8,15,21,22)$ with promising results regarding periodontal regeneration, and their clinical results have been shown to be significantly better than those of their comparative controls $(14,15,23-29)$.

Esposito et al. (30) and Koop et al. (31) demonstrated by systematic reviews that the use of EMDP may be a feasible clinical alternative with slightly superior clinical results to those of conventional periodontal treatment for the management of IPD. In spite of finding great variability in the results, neither one of them made an analysis of the clinical results, comparing differences in the follow-up time of the studies.

In view of the afore-mentioned issues, the propose of the present systematic review with meta-analysis was to test the null hypothesis that there would be no differences among studies with up to 12 months or 24 months or more of follow-up. 


\section{Material and Methods}

Research Questions

The present study addressed two specific questions: 1) What was the effect of EMDP when compared with open flap debridement (OFD) in IPD in a period of at least 12 months, with regards to alterations in probing depth (PD) and clinical attachment levels (CAL)? 2) Are these results maintained over 24 months?

\section{Search Strategy}

The search strategy was attained in electronic databases (Medline - Pubmed, LILACS, Cochrane Central Register of Controlled Trials, Embase and Web of Science). The search was conducted without time limit up to August 2013. The following strategy was conducted in PubMed. Adaptations of this strategy were done for the other databases. In the LILACS database, Portuguese and Spanish languages were used to set up the search strategy.

$[<(\{$ Patient $\}$ AND \{Intervention $\})>]$

Patient: $(((C(C((($ "periodontal flap"[All Fields] OR "modified widman"[All Fields]) OR "periodontal surgery"[All Fields]) OR "widman flap"[All Fields]) OR "open flap"[All
Fields]) OR "placebos"[MeSH Terms]) OR "placebo"[All Fields])))) OR (((((((("periodontal attachment loss"[All Fields] OR "attachment loss"[All Fields]) OR "attachment level"[All Fields]) OR "probing depth"[All Fields]) OR "probing pocket depth"[All Fields]) OR "gingival recession"[All Fields]) OR (("Periodontal Attachment Loss"[Mesh] OR "Periodontal Pocket"[Mesh]) OR "Gingival Recession"[Mesh]))))) OR (((c((c((()((()((("periodontitis"[All Fields] OR "aggressive periodontitis"[All Fields]) OR "juvenile periodontitis"[All Fields]) OR "prepubertal periodontitis"[All Fields]) OR "chronic periodontitis"[All Fields]) OR "adult periodontitis"[All Fields]) OR "infrabony defect"[All Fields]) OR "infrabony defects"[All Fields]) OR "infrabony lesions"[All Fields]) OR "infrabony osseous defects"[All Fields]) OR "infrabony periodontal defects"[All Fields]) OR "infrabony periodontal pockets"[All Fields]) OR "angular defects"[All Fields]) OR (("Periodontitis"[Mesh] OR "Chronic Periodontitis"[Mesh] OR "Aggressive Periodontitis"[Mesh]) OR "Periodontal Diseases"[Mesh]))))).

Intervention: (c(c((("enamel matrix derivative"[All Fields] OR "enamel matrix derivatives"[All Fields]) OR "enamel matrix derivative emdogain"[All Fields]) OR "enamel matrix

Table 1. Evaluation of methodological quality of studies included

\begin{tabular}{|c|c|c|c|c|c|c|c|c|c|c|}
\hline $\begin{array}{l}\text { Authors/Year of } \\
\text { publication }\end{array}$ & $\begin{array}{c}\text { Sample } \\
\text { size } \\
(0-2)\end{array}$ & $\begin{array}{c}\text { Randomization } \\
\qquad(0-2)\end{array}$ & $\begin{array}{c}\text { Allocation } \\
\text { concealment } \\
(0-2)\end{array}$ & $\begin{array}{l}\text { Inclusion } \\
\text { and/or } \\
\text { exclusion } \\
\text { criteria } \\
(0-1)\end{array}$ & $\begin{array}{l}\text { Follow- } \\
\text { up } \\
(0-1)\end{array}$ & $\begin{array}{c}\text { Experimental } \\
\text { and control } \\
\text { group } \\
\text { baseline } \\
(0-2)\end{array}$ & $\begin{array}{l}\text { Blinding } \\
(0-1)\end{array}$ & $\begin{array}{c}\text { Statistical } \\
\text { analysis } \\
(0-2)\end{array}$ & Sum & $\begin{array}{c}\text { Estimated } \\
\text { risk of } \\
\text { bias }\end{array}$ \\
\hline Zetterström (1997) & 0 & 0 & 0 & 1 & 1 & 1 & 0 & 1 & 4 & High \\
\hline Silvestri (2000) & 0 & 0 & 0 & 1 & 1 & 1 & 0 & 2 & 5 & High \\
\hline Okuda (2000) & 0 & 2 & 2 & 1 & 1 & 1 & 1 & 2 & 10 & Moderate \\
\hline Froum (2001) & 0 & 2 & 2 & 1 & 1 & 0 & 1 & 2 & 9 & Moderate \\
\hline Wachtel (2003) & 2 & 2 & 2 & 1 & 0 & 1 & 1 & 2 & 11 & Moderate \\
\hline Francetti (2004) & 0 & 1 & 0 & 1 & 1 & 1 & 1 & 2 & 7 & Moderate \\
\hline Mombelli (2005) & 0 & 2 & 0 & 1 & 1 & 2 & 1 & 1 & 8 & Moderate \\
\hline Bokan (2006) & 0 & 2 & 0 & 1 & 1 & 1 & 1 & 2 & 8 & Moderate \\
\hline Sculean (2008) & 1 & 2 & 0 & 1 & 1 & 1 & 1 & 2 & 9 & Moderate \\
\hline Grusovin (2009) & 2 & 2 & 2 & 1 & 1 & 1 & 0 & 1 & 10 & Moderate \\
\hline Filckl (2009) & 0 & 2 & 1 & 1 & 1 & 1 & 0 & 1 & 7 & Moderate \\
\hline Chambrone (2010) & 2 & 2 & 2 & 1 & 0 & 1 & 1 & 1 & 10 & Moderate \\
\hline Cortellini (2011) & 1 & 2 & 2 & 1 & 1 & 1 & 0 & 2 & 10 & Moderate \\
\hline Bhutda (2013) & 0 & 2 & 1 & 0 & 1 & 2 & 0 & 2 & 8 & Moderate \\
\hline Heijl (1997) & 2 & 2 & 2 & 1 & 1 & 0 & 1 & 2 & 11 & Low \\
\hline Tonetti (2002) & 2 & 2 & 2 & 1 & 1 & 2 & 0 & 2 & 12 & Low \\
\hline Francetti (2005) & 0 & 2 & 2 & 1 & 1 & 2 & 1 & 2 & 11 & Low \\
\hline Rösing (2005) & 2 & 2 & 2 & 1 & 1 & 2 & 1 & 2 & 13 & Low \\
\hline De Leonardi (2013) & 2 & 2 & 2 & 1 & 1 & 1 & 1 & 2 & 12 & Low \\
\hline
\end{tabular}


derived protein"[All Fields]) OR "enamel matrix derived proteins"[All Fields]) OR "enamel matrix proteins"[All Fields]) OR "enamel matrix proteins amelogenin"[All Fields]) OR "emdogain"[All Fields]) OR (("enamel matrix proteins"[Supplementary Concept] OR "Dental Enamel Proteins"[Mesh]) OR "Amelogenin"[Mesh]))).

A manual digital search between January 1995 and August 2012 was conducted in the tables of contents of the following journals: Journal of Clinical Periodontology, Journal of Periodontology, Journal of Periodontal Research and International Journal of Periodontics \& Restorative Dentistry. In addition, a manual search was made in the references of the included studies to verify the existence of any study not found in the electronic search.

\section{Eligibility Criteria}

To be considered eligible, studies should have a Randomized Controlled Trial (RCT) design, split-mouth or parallel-arm trials, with one intervention group using EMDPs, and the control group having instrumentation performed with surgical access (OFD) with or without a placebo. Additional to that, a minimum follow-up period of 12 months; studies should have been performed in humans with chronic or aggressive periodontitis with treatment of infra-bony lesions on 1, 2 or 3 walls; PD and CAL should have been evaluated as main outcomes. In addition, GR (Gingival recession) and/or BL (bone loss) could be present as secondary evaluation(s); no additional regenerative procedure should have been used; studies should be published in any language.

\section{Selection of Studies}

After this first stage of general search, two independent examiners (FGS and FBZ) evaluated all of these studies. In the first stage, studies were included or not by their titles; in the second, by their abstract, and in the third stage, after reading of the entire paper (Fig. 1). At the end of each stage, the examiners met and discussed divergences until they reached a consensus. The papers were selected according to pre-defined eligibility criteria.

\section{Quality Scores of Selected Studies}

A. Was there a sample size calculation? 0 No/not mentioned; 1 Yes, but not confirmed by calculation; 2 Yes, confirmed / B. Randomizations were categorized as (0) unclear, when the method was not reported or explained; (1) inadequate, when other methods were used (such as alternate assignment, hospital number, odd/even birth date, etc.) and (2) adequate, when a table of random numbers or a tossed coin or shuffled cards were used / C. Allocation concealment was categorized as (0): unclear, when the method was not reported or explained; (1): inadequate, when other methods were used (such as alternate assignment, hospital number, odd/even birth date, etc.) and (2) adequate, when examiners were kept unaware of the randomization sequence (for example, by means of central randomization, pharmacy sequentially numbered/coded containers, sequentially numbered opaque envelopes) / D. Were the inclusion/exclusion criteria clearly defined? 0 No 1 Yes / E. Completeness of follow-up was categorized dichotomously ( $0 \mathrm{No} / 1 \mathrm{Yes}$ ) by answering these questions: Was the number of patients at baseline and at completion of the follow-up interval reported for both experimental and control groups? Were all the patients who entered the trial properly accounted for at completion? Did the analysis take into account the drop-outs/losses to follow-up or the excluded patients? / F. Were the control and treatment groups comparable at entry for important prognostic factors? 0 No 1 Unclear 2 Yes / G. Was there any attempt at blinding (for example, independent assessor)? 0 No 1 Yes / $\mathrm{H}$. Was the statistical analysis appropriate? 0 No 1 Unclear 2 Yes. Quality assessment was carried out independently by two reviewers (FGS and FBZ). If disagreement occurred, a discussion was held until consensus was reached. The total score for the study was counted. Studies with score $<07$ points were considered to have high risk of bias, scores between 07-10 moderate risk of bias, and scores $>10$ with low risk of bias.

\section{Data Extraction}

In each study, data related to clinical outcomes at baseline, in final examinations and differences between treatments were evaluated. For data analysis, Review Manager 5.1 software (RevMan version 5.1 for Windows, Copenhagen: The Nordic Cochrane Center, The Cochrane

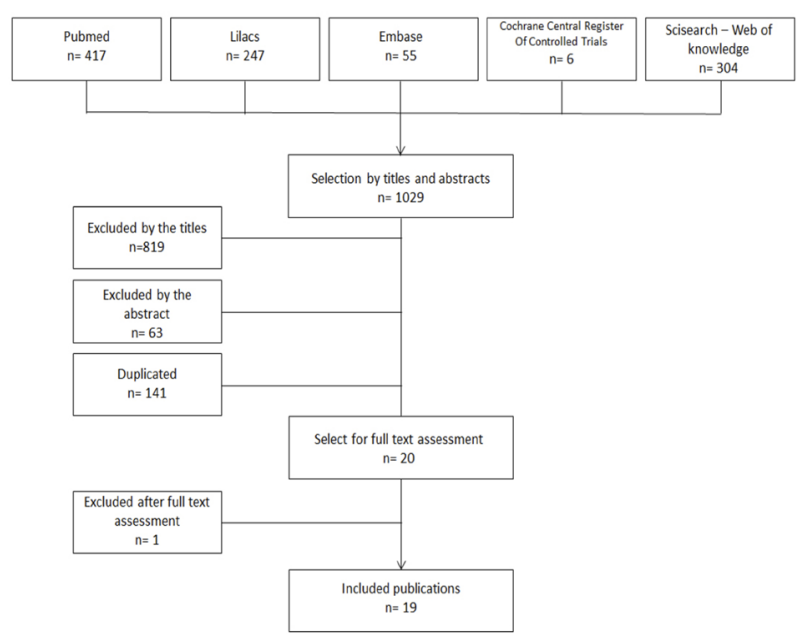

Figure 1. Flowchart of study design. 
Collaboration) was used. Mean differences and 95\% Confidence Intervals of differences $(95 \% \mathrm{Cl})$ were calculated for PD and CAL. Random effects models were used for continuous data. Statistical heterogeneity was evaluated by Cochran's test, where $p$ values below 0.1 were considered heterogeneous. The degree of inconsistency was verified by the $I^{2}$ test. An analysis by sub-groups was performed considering the follow-up time (studies $\geq 24$ months / up to 12 months follow-up) and the risk of bias (high and moderate risk/low risk) using the random effects model due to the heterogeneity detected (Figs. 2, 3, 4 and 5).

\section{Results}

In the first stage, 1029 studies (Lilacs: 247 studies, Pubmed: 417 studies, Web of Science: 304 studies, Embase: 55, Cochrane: 06 studies) were selected. Out of these, 819 were excluded by the title, 63 by the abstract, 141 were duplicated; finally, 20 were retrieved for complete reading (Fig. 1). Moreover, 1 study was excluded after this last stage, so that 19 eligible studies remained.

\section{Study Characteristics}

Of the 19 studies included, nine had a split-mouth design - six with a follow-up period of 12 months $(14,16,23,27,28,34)$ and three with duration of over 24 months $(15,35,36)$ - and ten had a parallel design - five with a follow-up period of 12 months $(10,17,37-39)$ and five with a follow-up period of over 24 months $(24,25,29,40,41)$. Regarding the evaluated outcomes, $\mathrm{PD}$ and CAL were evaluated in all the studies, gingival recession (GR) was additionally evaluated in eight studies $(15,16,24,25,29,36,39,41)$ and bone filling in twelve studies $(10,14-16,23-25,27,29,36,39,41)$. As to the methodological quality, five studies presented low risk of bias $(7,16,17,25,41)$, twelve had moderate risk $(10,14,23,24,27,28,34-37,39,40)$ and two had high risk $(29,38)$ of bias.

\section{Meta-Analysis Results}

According to the results of the meta-analysis of subgroups with inclusion of the 19 studies, considering the probing depth, high statistical heterogeneity was detected in the analysis of PD in studies with up to 12 months $\left(p<0.00001 \mathrm{l}^{2}=91 \%\right)$ or over 24 months of follow-up (Fig. 2), $\left(p<0.00001 \mathrm{I}^{2}=82 \%\right)$. In the analysis of $C A L$, there was high heterogeneity in studies of 12 months $\left(p<0.00001 l^{2}=86 \%\right)$ and low heterogeneity in those with over 24 months of follow-up (Fig. 3), ( $\left.p=0.08 I^{2}=45 \%\right)$. Similar parameters were observed considering probing depth, high statistical heterogeneity was detected in the analysis of PD in studies with moderate and high bias $\left(\mathrm{p}<0.00001 \mathrm{I}^{2}=88 \%\right)$ and low bias studies (Fig. 4), $\left(p<0.003 \mathrm{I}^{2}=75 \%\right)$. In the analysis of $\mathrm{CAL}$, there was high heterogeneity in studies with moderate and high bias $\left(p<0.00001 \mathrm{I}^{2}=85 \%\right)$ and in those with low bias (Fig. 5), ( $\left.p=0.01 I^{2}=70 \%\right)$.

\begin{tabular}{|c|c|c|c|c|c|c|c|c|c|c|c|}
\hline \multirow{2}{*}{ Study or Subgroup } & \multicolumn{3}{|c|}{ EMDP } & \multicolumn{3}{|c|}{ OFD } & \multicolumn{2}{|r|}{ Mean Difference } & \multirow{2}{*}{\multicolumn{2}{|c|}{$\begin{array}{l}\text { Mean Difference } \\
\text { IV, Random, } 95 \% \mathrm{CI}\end{array}$}} & \\
\hline \multirow{2}{*}{\multicolumn{11}{|c|}{2.2 .1 up to 12 months }} & \\
\hline & & & & & & & & & & & \\
\hline Bhutda 2013 & 4.12 & 1.1 & 15 & 2.22 & 0.15 & 15 & $5.2 \%$ & $1.90[1.34,2.46]$ & & & \\
\hline Bokan 2006 & 3.9 & 1.3 & 19 & 3.8 & 1.8 & 18 & $4.0 \%$ & $0.10[-0.92,1.12]$ & & & \\
\hline Chambrone 2010 & 4 & 0.1 & 10 & 3.49 & 0.46 & 10 & $5.7 \%$ & $0.51[0.22,0.80]$ & & $\rightarrow$ & \\
\hline Cortellini 2011 & 4.4 & 1.2 & 15 & 4.4 & 1.6 & 15 & $4.0 \%$ & $0.00[-1.01,1.01]$ & & & \\
\hline De Leonardi 2013 & 3.51 & 0.58 & 34 & 2.58 & 0.55 & 34 & $5.7 \%$ & $0.93[0.66,1.20]$ & & & \\
\hline Filckl 2009 & 4.2 & 0.3 & 35 & 2.4 & 0.3 & 35 & $5.9 \%$ & $1.80[1.66,1.94]$ & & & - \\
\hline Froum 2001 & 4.94 & 2.65 & 53 & 2.24 & 1.28 & 31 & $4.5 \%$ & $2.70[1.86,3.54]$ & & & \\
\hline Grusovin 2009 & 4.2 & 1.6 & 15 & 3.9 & 1 & 15 & $4.2 \%$ & $0.30[-0.65,1.25]$ & & & \\
\hline Mombelli 2005 & 2.2 & 1.9 & 14 & 2 & 1.4 & 14 & $3.5 \%$ & $0.20[-1.04,1.44]$ & & & \\
\hline Okuda 2000 & 3 & 0.97 & 16 & 2.22 & 0.81 & 16 & $5.0 \%$ & $0.78[0.16,1.40]$ & & & \\
\hline Rösing 2005 & 4.17 & 1.82 & 14 & 4.39 & 1.07 & 14 & $3.8 \%$ & $-0.22[-1.33,0.89]$ & & & \\
\hline Sculean 2008 & 4.1 & 1.5 & 10 & 3.7 & 1.6 & 9 & $3.1 \%$ & $0.40[-1.00,1.80]$ & & & \\
\hline Silvestri 2000 & 4.8 & 1.6 & 10 & 1.4 & 1.3 & 10 & $3.4 \%$ & $3.40[2.12,4.68]$ & & & \\
\hline Tonetti 2002 & 3.9 & 1.7 & 14 & 4.39 & 1.07 & 14 & $3.9 \%$ & $-0.49[-1.54,0.56]$ & & & \\
\hline Wachtel 2003 & 3.9 & 1.4 & 13 & 2.1 & 1.1 & 13 & $4.1 \%$ & $1.80[0.83,2.77]$ & & & \\
\hline \multirow{2}{*}{\multicolumn{12}{|c|}{$\begin{array}{l}\text { Heterogeneity: } \mathrm{Tau}^{2}=0.60 ; \mathrm{Chi}^{2}=149.56, \mathrm{df}=14(\mathrm{P}<0.00001) ; \mathrm{I}^{2}=91 \% \\
\text { Test for overall effect: } \mathrm{Z}=4.23(\mathrm{P}<0.0001)\end{array}$}} \\
\hline & & & & & & & & & & & \\
\hline \multicolumn{12}{|c|}{ 2.2.2 24 months or more } \\
\hline Bhutda 2013 & 3.84 & 1.05 & 15 & 1.92 & 0.35 & 15 & $5.2 \%$ & $1.92[1.36,2.48]$ & & & \\
\hline Chambrone 2010 & 2.09 & 0.97 & 19 & 2.85 & 1.42 & 19 & $4.6 \%$ & $-0.76[-1.53,0.01]$ & & & \\
\hline De Leonardi 2013 & 3.76 & 0.84 & 34 & 2.38 & 1.01 & 34 & $5.4 \%$ & $1.38[0.94,1.82]$ & & & \\
\hline Francetti 2004 & 4.86 & 1.95 & 11 & 3 & 1.15 & 11 & $3.2 \%$ & $1.86[0.52,3.20]$ & & & \\
\hline Francetti 2005 & 4.02 & 4.99 & 83 & 3.51 & 4.9 & 70 & $2.8 \%$ & $0.51[-1.06,2.08]$ & & & \\
\hline Heijl 1997 & 3.1 & 1 & 27 & 2.3 & 1.1 & 27 & $5.2 \%$ & $0.80[0.24,1.36]$ & & & \\
\hline Sculean 2008 & 3.6 & 1.5 & 10 & 3.5 & 1.4 & 9 & $3.3 \%$ & $0.10[-1.20,1.40]$ & & & \\
\hline $\begin{array}{l}\text { Zetterström } 1997 \\
\text { Subtotal }(95 \% \mathrm{CI})\end{array}$ & 3.8 & 1.8 & $\begin{array}{r}90 \\
289\end{array}$ & 3.2 & 2 & $\begin{array}{r}21 \\
206\end{array}$ & $\begin{array}{r}4.2 \% \\
34.0 \%\end{array}$ & $\begin{array}{r}0.60[-0.33,1.53] \\
0.83[0.19,1.48]\end{array}$ & & & \\
\hline \multicolumn{12}{|c|}{$\begin{array}{l}\text { Heterogeneity: } \mathrm{Tau}^{2}=0.64 ; \mathrm{Chi}^{2}=38.01, \mathrm{df}=7(\mathrm{P}<0.00001) ; \mathrm{I}^{2}=82 \% \\
\text { Test for overall effect: } \mathrm{Z}=2.53(\mathrm{P}=0.01)\end{array}$} \\
\hline Total $(95 \% \mathrm{Cl})$ & & & 576 & & & 469 & $100.0 \%$ & $0.93[0.57,1.29]$ & & & \\
\hline \multicolumn{9}{|c|}{$\begin{array}{l}\text { Heterogeneity: } \mathrm{Tau}^{2}=0.57 ; \mathrm{Chi}^{2}=193.81, \mathrm{df} \\
\text { Test for overall effect: } \mathrm{Z}=5.07(\mathrm{P}<0.00001) \\
\text { Test for subgroup differences: } \mathrm{Chi}^{2}=0.13, \mathrm{df}=\end{array}$} & $\begin{array}{ccc}-1 & -1 & 0 \\
\text { Favours control }\end{array}$ & $F$ & 2 \\
\hline
\end{tabular}

Figure 2. Meta-analysis for probing depth considering only studies up to 12 months and 24 months or more of follow-up. 
In the general results of the meta-analysis, EMDPs presented statistically better results than those of their respective controls, with a mean difference of $0.93 \mathrm{~mm}$
(Cl95\% $0.57-1.29$ ) and $1.15 \mathrm{~mm}$ (Cl95\% $0.74-1.48$ ) for PD and CAL, respectively. Studies with 12 months of follow-up presented a mean difference of $0.97 \mathrm{~mm}$ (C195\%

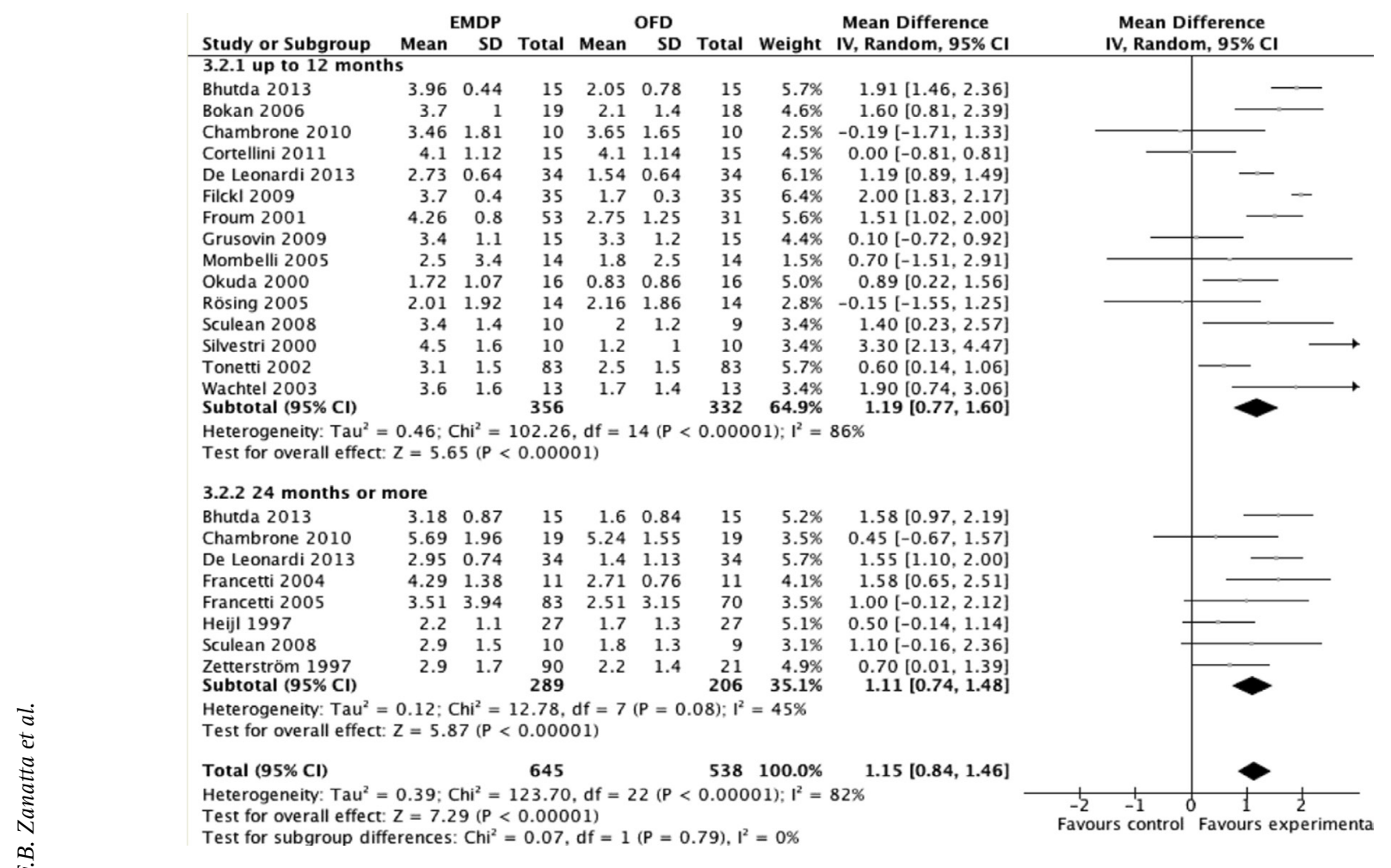

Figure 3. Meta-analysis for attachment level considering only studies up to 12 months and 24 months or more of follow-up.

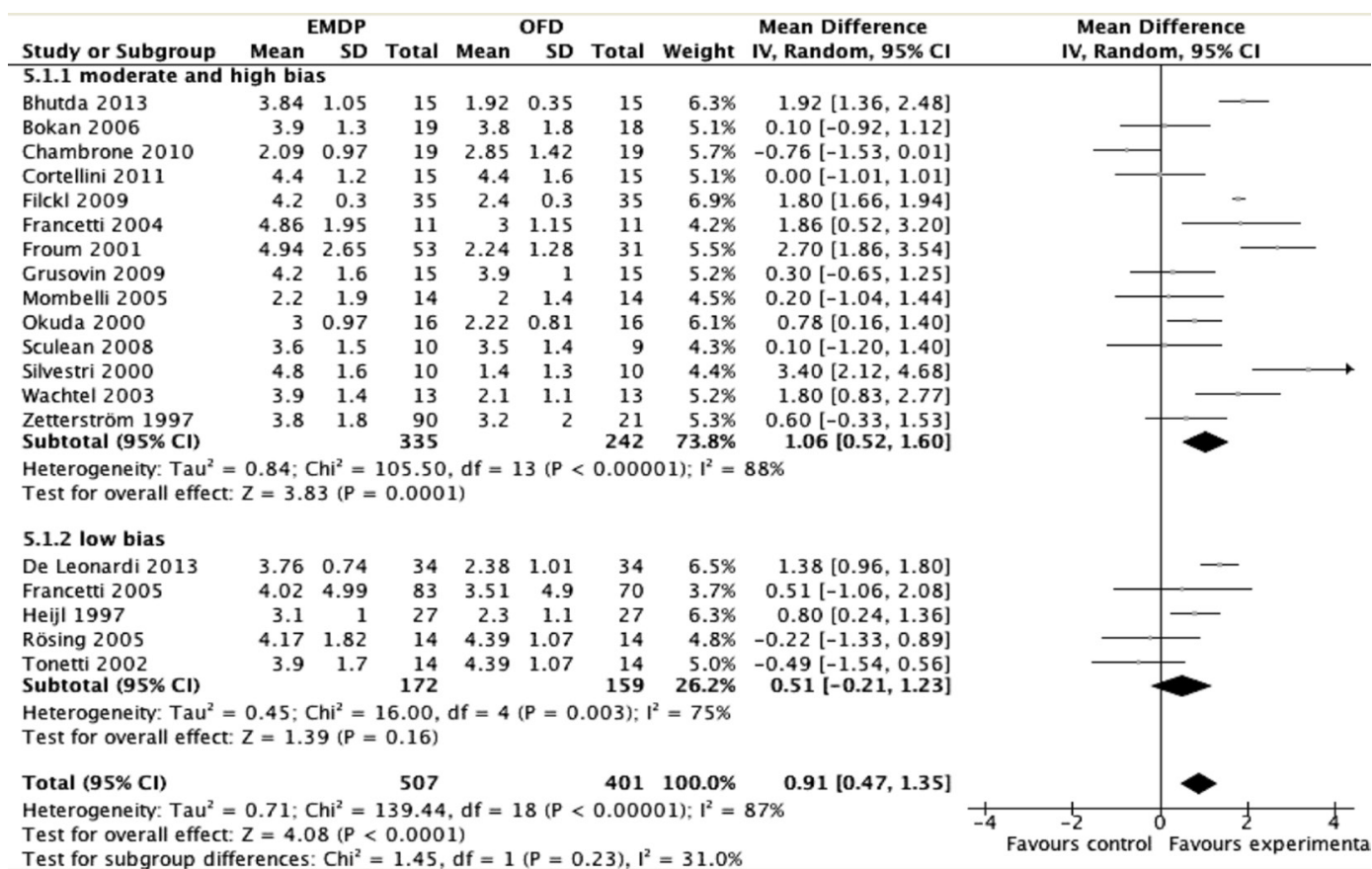

Figure 4. Meta-analysis for probing depth considering only studies with high/moderate and low risk of bias. 
0.52 -1.43) for PD (Fig. 2) and $1.19 \mathrm{~mm}$ (Cl95\% $0.77-1.60)$ for CAL (Fig. 3), favorable to EMDPs. In studies with over two years of follow-up, the mean differences were also favorable to EMDPs with $0.93 \mathrm{~mm}$ (CI95\% 0.57 - 1.29) and
$1.11 \mathrm{~mm}$ (Cl95\% 0.84 - 1.48) for PD (Fig. 2) and CAL (Fig. 3), respectively. Considering the risk of bias, studies with high and moderate risk of bias showed differences favorable to EMDPs, of the magnitude of $1.06 \mathrm{~mm}$ (Cl95\% 0.52 - 1.60)

\begin{tabular}{|c|c|c|c|c|c|c|c|c|c|c|}
\hline \multirow[b]{2}{*}{ Study or Subgroup } & \multicolumn{3}{|c|}{ EMDP } & \multicolumn{3}{|c|}{ OFD } & \multirow[b]{2}{*}{ Weight } & \multirow{2}{*}{$\begin{array}{l}\text { Mean Difference } \\
\text { IV, Random, } 95 \% \mathrm{CI}\end{array}$} & \multirow{2}{*}{\multicolumn{2}{|c|}{$\begin{array}{l}\text { Mean Difference } \\
\text { IV, Random, 95\% CI }\end{array}$}} \\
\hline & Mean & SD & Total & Mean & SD & Total & & & & \\
\hline \multicolumn{11}{|c|}{ 5.2.1 moderate or high bias } \\
\hline Bhutda 2013 & 3.18 & 0.87 & 15 & 1.6 & 0.54 & 15 & $6.4 \%$ & $1.58[1.06,2.10]$ & & \\
\hline Bokan 2006 & 3.7 & 1 & 19 & 2.1 & 1.4 & 18 & $5.4 \%$ & $1.60[0.81,2.39]$ & & \\
\hline Chambrone 2010 & 5.69 & 1.96 & 19 & 5.24 & 1.55 & 19 & $4.3 \%$ & $0.45[-0.67,1.57]$ & & \\
\hline Cortellini 2011 & 4.4 & 1.2 & 15 & 4.4 & 1.2 & 15 & $5.2 \%$ & $0.00[-0.86,0.86]$ & & \\
\hline Filckl 2009 & 3.7 & 0.4 & 35 & 1.7 & 0.3 & 35 & $7.2 \%$ & $2.00[1.83,2.17]$ & & - \\
\hline Francetti 2004 & 4.29 & 1.38 & 11 & 2.71 & 0.76 & 11 & $4.9 \%$ & $1.58[0.65,2.51]$ & & \\
\hline Froum 2001 & 4.26 & 0.8 & 53 & 2.75 & 1.25 & 31 & $6.5 \%$ & $1.51[1.02,2.00]$ & & \\
\hline Grusovin 2009 & 3.4 & 1.1 & 15 & 3.3 & 1.2 & 15 & $5.3 \%$ & $0.10[-0.72,0.92]$ & & \\
\hline Mombelli 2005 & 2.5 & 3.4 & 14 & 1.8 & 2.5 & 14 & $2.0 \%$ & $0.70[-1.51,2.91]$ & & \\
\hline Okuda 2000 & 1.72 & 1.07 & 16 & 0.83 & 0.86 & 16 & $5.8 \%$ & $0.89[0.22,1.56]$ & & \\
\hline Sculean 2008 & 2.9 & 1.5 & 10 & 2.16 & 1.86 & 14 & $3.6 \%$ & $0.74[-0.61,2.09]$ & & \\
\hline Silvestri 2000 & 3.1 & 1.5 & 83 & 2.5 & 1.5 & 83 & $6.6 \%$ & $0.60[0.14,1.06]$ & & \\
\hline Wachtel 2003 & 3.6 & 1.6 & 13 & 1.7 & 1.4 & 13 & $4.2 \%$ & $1.90[0.74,3.06]$ & & \\
\hline $\begin{array}{l}\text { Zetterström } 1997 \\
\text { Subtotal }(\mathbf{9 5} \% \mathrm{Cl})\end{array}$ & 2.9 & 1.7 & $\begin{array}{r}90 \\
408\end{array}$ & 2.2 & 1.4 & $\begin{array}{r}21 \\
320\end{array}$ & $\begin{array}{r}5.8 \% \\
73.1 \%\end{array}$ & $\begin{array}{c}0.70[0.01,1.39] \\
1.07[0.64,1.50]\end{array}$ & & \\
\hline \multicolumn{11}{|c|}{$\begin{array}{l}\text { Heterogeneity: } \mathrm{Tau}^{2}=0.48 ; \mathrm{Chi}^{2}=84.27, \mathrm{df}=13(\mathrm{P}<0.00001) ; \mathrm{I}^{2}=85 \% \\
\text { Test for overall effect: } \mathrm{Z}=4.89(\mathrm{P}<0.00001)\end{array}$} \\
\hline \multicolumn{11}{|l|}{5.2 .2 low bias } \\
\hline De Leonardi 2013 & 2.95 & 0.74 & 34 & 1.4 & 1.13 & 34 & $6.6 \%$ & $1.55[1.10,2.00]$ & & \\
\hline Francetti 2005 & 3.51 & 3.94 & 83 & 2.51 & 3.15 & 70 & $4.3 \%$ & $1.00[-0.12,2.12]$ & & \\
\hline Heijl 1997 & 2.2 & 1.1 & 27 & 1.7 & 1.3 & 27 & $5.9 \%$ & $0.50[-0.14,1.14]$ & & \\
\hline Rösing 2005 & 2.01 & 1.92 & 14 & 2.16 & 1.86 & 14 & $3.5 \%$ & $-0.15[-1.55,1.25]$ & & \\
\hline $\begin{array}{l}\text { Tonetti } 2002 \\
\text { Subtotal }(95 \% \mathrm{CI})\end{array}$ & 3.1 & 1.5 & $\begin{array}{r}83 \\
241\end{array}$ & 2.5 & 1.5 & $\begin{array}{r}83 \\
228\end{array}$ & $\begin{array}{r}6.6 \% \\
26.9 \%\end{array}$ & $\begin{array}{l}0.60[0.14,1.06] \\
0.80[0.24,1.36]\end{array}$ & & \\
\hline \multicolumn{11}{|c|}{$\begin{array}{l}\text { Heterogeneity: } \text { Tau }^{2}=0.25 ; \mathrm{Chi}^{2}=13.19, \mathrm{df}=4(\mathrm{P}=0.01) ; \mathrm{I}^{2}=70 \% \\
\text { Test for overall effect: } Z=2.82(\mathrm{P}=0.005)\end{array}$} \\
\hline Total $(95 \% \mathrm{Cl})$ & & & 649 & & & 548 & $100.0 \%$ & $0.99[0.63,1.35]$ & & \\
\hline \multicolumn{9}{|c|}{$\begin{array}{l}\text { Heterogeneity: } \mathrm{Tau}^{2}=0.47 ; \mathrm{Chi}^{2}=117.02, \mathrm{df}=18(\mathrm{P}<0.00001) ; \mathrm{I}^{2}=85 \% \\
\text { Test for overall effect: } Z=5.37(\mathrm{P}<0.00001) \\
\text { Test for subgroup differences: } \mathrm{Chi}^{2}=0.55, \mathrm{df}=1(\mathrm{P}=0.46), \mathrm{I}^{2}=0 \%\end{array}$} & $\begin{array}{ccc}-1 & -1 & 0 \\
\text { Favours control } & 0\end{array}$ & $\begin{array}{c}1 \\
\text { ours }\end{array}$ \\
\hline
\end{tabular}

Figure 5. Meta-analysis for attachment level considering only studies with high/moderate and low risk of bias.
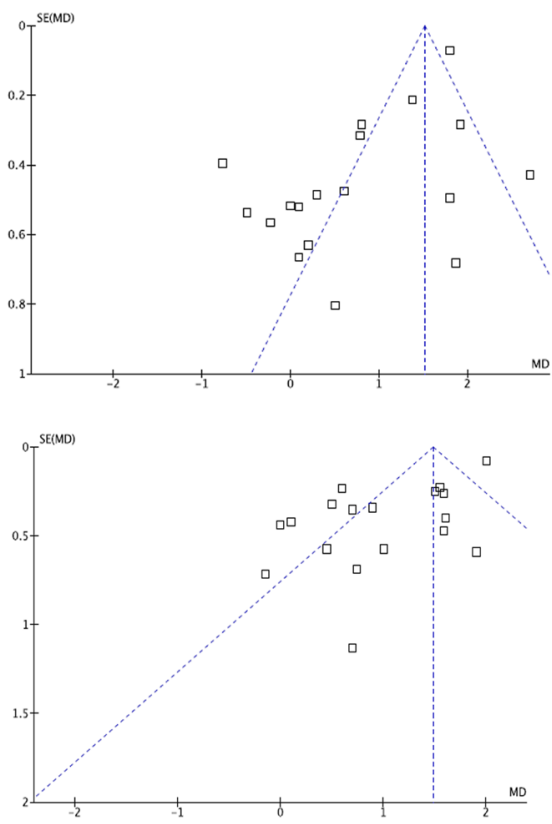

Figure 6. Funnel plot from included studies. The upper graph refers to probing depth and the lower graph refers to clinical attachment loss. 
for PD (Fig. 4) and $0.99 \mathrm{~mm}$ (Cl95\% 0.63 - 1.35) for CAL (Fig. 5). However, in studies with low risk of bias, the EMDPs showed lower results in favor of EMDPs group for CAL 0.80 $\mathrm{mm}$ (CI95\% 0.24 - 1.36) (Fig. 5) without differences for PD

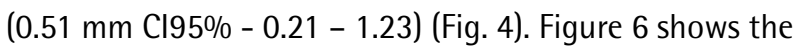
funnel plot for PD and NIC evidencing the possibility of publication bias since there is a clear trend of studies to show differences favoring EMDPs.

\section{Discussion}

The present systematic review assessed clinical results of EMDP as compared to OFD in IPDs and demonstrated that the published literature indicates slight benefits with the use of EMDPs, especially when overtime results are considered, as well as taking the quality of the studies into consideration. Information obtained by means of periodontal probing, radiographs and re-entry procedures are limited in determining the quality, quantity and nature of the newly formed supporting tissues (42). Alterations in probing depth reflect inflammatory changes and clinical attachment gains that may be obtained without new formation of the periodontium, due to resolution of inflammation, bone filling, collagen fiber reorganization and formation of the long junctional epithelium. Thus, probing does not offer direct proof of periodontal neoformation and therefore does not constitute an adequate instrument for the evaluation of regenerative processes. However, clinicians use probing as the gold standard for evaluating patients. This means that clinical evaluations are useful, but cannot assure regeneration. Bone levels after the use of EMDP may be compared with the initial bone levels as an interesting outcome. Eleven studies $(10,15,16,23-$ $25,27,29,36,39,41)$ observed bone filling in radiographs, and in only one study it was performed in re-entry surgeries (14). Nevertheless, it is important to point out that bone measurements do not reflect connective attachment levels. In addition, bone height, density and volume may be estimated pre- and post-treatment, however without reflecting alterations in connective tissue $(42,43)$. Therefore, it is evident that clinical and radiographic methods are not safe in the determination of the healing pattern that occurs after regenerative therapy.

Histologic evaluation is the only reliable method for determining the efficacy of regenerative therapies. It allows for evaluation of all the components of the periodontium and thus, will faithfully determine whether the clinical results represent neoformation of the periodontal tissues or any form of repair. Due to ethical considerations, histologic evaluation is mostly performed in animal models rather than in humans. Sculean et al. (20) demonstrated that regeneration is attained in monkeys after the use of EMDP, however with varied extensions in the different types of produced defects. Using dogs, Alhezaimi et al. (19) demonstrated complete regeneration (new cement, inserted ligament and bone tissue) in only 3 of the 15 defects treated with EMDP, with an extension of $58 \% \pm 4 \%$ in height. The other sites treated with EMDP exhibited formation of new cement and periodontal ligament only, in varied extensions, and this fact also occurred in 20\% of the control sites. Human histological studies with EMDP comprised limited number of patients and therefore should not be considered in terms of validity. The meta-analysis performed in this review demonstrated results for PD and CAL that were consistently favorable to the EMDP group. However, high heterogeneity was detected for PD, irrespective of the period of follow-up time, and for CAL this occurred in studies with follow-up periods of less than 12 months. Venezia et al. (44) also found results favorable to the enamel matrix derivatives, however, their systematic review with meta-analysis presents some methodological issues that prevent safe extrapolation of their findings. The obtained results are in line with two well-conducted systematic reviews about the same subject $(30,31)$. However, differently from these two reviews, this study performed analyses by subgroups, considering follow-up time, suggesting that the magnitude of differences between the use of EMDP and OFD considerably decreases over time. Thus, it could be hypothesized that in some of the sites treated with EMDP, the formation of LE occurred after the use of EMDP, and thus they presented a healing pattern similar to that of the control groups. Moreover, the factor that would justify the results of greater clinical magnitude in the first 12 months is that the EMDPs presented some immediate biologic effects, and these tended to diminish overtime, because although some of the sites treated with EMDP presented regeneration, this occurred in a reduced extension of the IPD.

Considering that studies with a stricter methodological approach are more reliable, when one considered only those with low risk of bias, the differences for CAL become less favorable to the EMDPs, without differences for PD. Studies with low risk of bias follow a strict research protocol which allows smaller systematic errors influence the research, decreasing the overestimation of the results (32).

The variability of the results is clear when the variations in reductions in probing depth and clinical attachment level are evaluated. It could be hypothesized that this heterogeneity may be explained by the fact that some studies used antibiotics $(14-16,24,25,27,29,34)$ and others did not $(10,17,23,26,28,30,35)$, by the variable surface treatments, inclusion of smokers $(10,14-17,23-$ $25,28,29,34,35)$, initial depth of defects and number of remaining bone walls, use of placebo gel in some studies $(10,15,16,27,34)$ and not in others $(14,17,23-26,28,29,35)$, 
differences in methodological quality, in addition to other variables that could influence the results, such as the surgical technique, quality of instrumentation and biofilm control performed by the patients (45).

Evidence has demonstrated that the topography of the IPD is directly related to its regenerative potential. Twoor three-wall defects are more easily regenerated when compared with defects with one wall, due to the presence of a larger number of bone walls and, consequently, a larger number of potential sources (periodontal and endosteal ligament) of cells able to differentiate into cementoblasts, osteoblasts and fibroblasts of the periodontal ligament (46). Moreover, the vertical and horizontal components of defects exert an influence on their regenerative potential. Deeper defects compete with more favorable prognoses, and angles smaller than $45^{\circ}$ formed between the root surface and bone wall show more predictability as regards regeneration than wider defects $\left(>45^{\circ}\right)(47)$. From this aspect, differences in the topographies of defects may also explain the high variability of the results, since defects with 1 and 2 walls were also included in the treatment groups.

In spite of the high heterogeneity detected for PD in studies with less than one or more than two years of followup, evaluation of the heterogeneity of CAL demonstrated differences in variability with the time of follow-up, in which studies with a follow-up period of over two years showed little variability in the results. This shows that irrespective of the methodological differences among the studies, CAL appears to be the most reliable outcome for evaluating the stability of the results in studies in which the use of EMDP in IPD is compared. A possible explanation is due to the possible fluctuations in PD resulting from edema or gingival margin recession, influenced by gingival margin inflammation, which are also influenced by the morphology of the subjacent bone wall. On the other hand, CAL is more related to the healing process in the apical portion of the IPD, being mainly influenced in the first two years by morphological variability of the defects and inter-individual biological variations (47).

The results relative to PD and CAL were shown to be consistently favorable to treatment with EMDP. However, when the magnitude of these differences is discussed one can observe advantages that do not exceed $1.17 \mathrm{~mm}$ for the evaluated parameters in studies with follow-up periods of over 24 months. Therefore, the clinical relevance of these differences can be questioned both from a magnitude point of view (since they are similar to probing margin of error) as well as from a longitudinal point of view, since the magnitude of the differences tends to decrease. Killoy (48) put forward some guidelines for evaluating whether the magnitude of the differences between treatments should be considered clinically significant: 1) Does the proposed treatment change the prognosis of the case? 2) Does it diminish or simplify future treatment? 3) Does it reduce the need for more aggressive therapies? 4) Does it modify or simplify the maintenance therapy? 5) Does it facilitate restorative treatment both for the patient and professional? 6) Is the cost-benefit ratio favorable? Having stated this, one also finds that there is still a lack of evidence that answer several of these questions when the use of EMDP is considered for the treatment of IPD. Studies concerning true endpoints as tooth loss, quality of life, etc., are therefore warranted.

One important aspect that needs to be put into perspective concerning the present study is publication bias. It is well known from the literature that studies that do not display statistically significant differences among tested groups tend not to be published. Also, studies that are supported by the industry have higher chance to present significant results. This factor was assessed in the present review in which it seems to be a clear trend of almost published studies to show differences favoring EMDP. Thus, it should be kept in mind while interpreting the present results, that it may be possible that additional studies, especially those without relevant benefits of EMDP have been performed and are not published due to publication bias (49).

It seems that despite being a goal, complete and predictable regeneration of the periodontium in infra-bony lesions with the use of EMDP apparently continues to be an unattainable objective. The results relative to PD and CAL are slightly superior to those obtained with conventional treatment. Therefore, in spite of EMDPs being a therapeutic alternative for the management of infrabony lesions, the variability, reduction in clinical differences after 2 years and cost-benefit of the procedure, should form part of the discussion with the patient for the decision-making process. In conclusion, EMDP presents slightly better clinical outcomes than OFD, which possibly decrease overtime. Additionally, the effects are lower in studies with lower risk of bias.

\section{Resumo}

Revisões sistemáticas prévias tem demonstrado melhores resultados com proteinas derivadas da matriz de esmalte (PDME) em comparação a retalho de espessura total (RET) para o manejo de defeitos periodontais infraósseos (DPI). 0 objetivo desse estudo foi determinar se essas diferenças variam de acordo com o tempo de acompanhamento e com a qualidade dos estudos. As bases de dados Cochrane Central Register of Controlled Trials, MEDLINE (PubMed), Lilacs, Embase e Web of Science foram pesquisadas sem limitação de tempo ate agosto de 2013 para ensaios clínicos randomizados. Os desfechos elegiveis foram alterações na profundidade de sondagem (PS), nivel de inserção clinica (NIC), recessão gengival (RG) e alterações ósseas (A0). Resultados: Estudos com acompanhamento de ate 12 meses mostraram diferenças de $0.97 \mathrm{~mm}$ (Cl95\% 0.52 - 1.43) e $1.19 \mathrm{~mm}$ (Cl95\% 0.77 - 1.60) para PS e NIC, favoráveis a PDME, respectivamente. Estudos com acompanhamento $\geq 24$ meses demonstraram vantagens de $1.11 \mathrm{~mm}$ 
(Cl95\% 0.74 -1.48) para NIC e $0.83 \mathrm{~mm}$ (Cl95\% 0.19 -1.48) para PS, com o uso de PDME. Considerando a qualidade dos estudos, publicações com baixo risco de viés exibiram menores diferenças entre os grupos apresentando $0.8 \mathrm{~mm}$ (Cl95\% 0.24-1.36) para o NIC, sem diferenças para PS $(0.51 \mathrm{~mm}, \mathrm{Cl} 95 \%-0.21-1.23)$. Pode-se concluir que o tempo de acompanhamento (< ou > 2anos) e o risco de viés são variáveis que influenciam nos resultados do tratamento com PDME em DPIO.

\section{References}

1. Armitage GC. Periodontal diseases: diagnosis. Ann Periodontol 1996;1:37-215.

2. Cortellini $P$, Tonetti MS. Focus on intrabony defects: guided tissue regeneration. Periodontol 2000 2000;22:104-132.

3. Becker W, Becker BE. Treatment of mandibular 3-wall intrabony defects by flap debridement and expanded polytetrafluoroethylene barrier membranes. Long-term evaluation of 32 treated patients. J Periodontol 1993;64:1138-1144.

4. Lynch $\mathrm{SE}$, Colvin RB, Antoniades HN. Growth factors in wound healing. Single and synergistic effects on partial thickness porcine skin wounds. J Clin Invest 1989;84:640-646.

5. Rosen PS, Reynolds MA, Bowers GM. The treatment of intrabony defects with bone grafts. Periodontol 2000 2000;22:88-103.

6. Cortellini P, Bowers GM. Periodontal regeneration of intrabony defects: an evidence-based treatment approach. Int J Periodontics Restorative Dent 1995;15:128-145.

7. Heijl L. Periodontal regeneration with enamel matrix derivative in one human experimental defect. A case report. J Clin Periodontol 1997;24:693-696.

8. Mellonig JT. Enamel matrix derivative for periodontal reconstructive surgery: technique and clinical and histologic case report. Int J Periodontics Restorative Dent 1999;19:8-19.

9. Cortellini P, Pini Prato G, Tonetti MS. Periodontal regeneration of human infrabony defects. II. Re-entry procedures and bone measures. J Periodontol 1993;64:261-268.

10. Grusovin MG, Esposito M. The efficacy of enamel matrix derivative (Emdogain) for the treatment of deep infrabony periodontal defects: a placebo-controlled randomised clinical trial. Eur J Oral Implantol 2009;2:43-54

11. Weltman R, Trejo PM, Morrison E, Caffesse R. Assessment of guided tissue regeneration procedures in intrabony defects with bioabsorbable and non-resorbable barriers. J Periodontol 1997;68:582-590.

12. Giannobile WV, Somerman MJ. Growth and amelogenin-like factors in periodontal wound healing. A systematic review. Ann Periodontol 2003;8:193-204.

13. Kalpidis $C D$, Ruben MP. Treatment of intrabony periodontal defects with enamel matrix derivative: a literature review. J Periodontol 2002;73:1360-1376.

14. Froum SJ, Weinberg MA, Rosenberg E, Tarnow D. A comparative study utilizing open flap debridement with and without enamel matrix derivative in the treatment of periodontal intrabony defects: a 12-month re-entry study. J Periodontol 2001;72:25-34.

15. Heijl L, Heden G, Svardstrom G, Ostgren A. Enamel matrix derivative (EMDOGAIN) in the treatment of intrabony periodontal defects. J Clin Periodontol 1997;24:705-714.

16. Rosing CK, Aass AM, Mavropoulos A, Gjermo P. Clinical and radiographic effects of enamel matrix derivative in the treatment of intrabony periodontal defects: a 12-month longitudinal placebocontrolled clinical trial in adult periodontitis patients. J Periodontol 2005;76:129-133.

17. Tonetti MS, Lang NP, Cortellini $P$, Suvan JE, Adriaens $P$, Dubravec $D$, et al.. Enamel matrix proteins in the regenerative therapy of deep intrabony defects. J Clin Periodontol 2002;29:317-325.

18. Bosshardt DD. Biological mediators and periodontal regeneration: a review of enamel matrix proteins at the cellular and molecular levels. J Clin Periodontol 2008;35(Suppl):87-105.

19. Alhezaimi K, Al-Shalan T, O'Neill R, Shapurian T, Naghshbandi J,

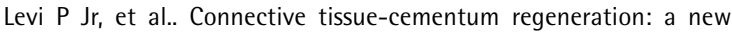
histologic regeneration following the use of enamel matrix derivative in dehiscence-type defects. A dog model. Int J Periodontics Restorative Dent 2009;29:425-433.

20. Sculean A, Donos N, Reich E, Karring T, Brecx M. Regeneration of oxytalan fibres in different types of periodontal defects: a histological study in monkeys. J Periodontal Res 1998;33:453-459.

21. Sculean A, Donos N, Windisch P, Brecx M, Gera I, Reich E, Karring T. Healing of human intrabony defects following treatment with enamel matrix proteins or guided tissue regeneration. J Periodontal Res 1999;34:310-322.

22. Yukna RA, Mellonig JT. Histologic evaluation of periodontal healing in humans following regenerative therapy with enamel matrix derivative. A 10-case series. J Periodontol 2000;71:752-759.

23. Fickl S, Thalmair T, Kebschull M, Bohm S, Wachtel H. Microsurgical access flap in conjunction with enamel matrix derivative for the treatment of intra-bony defects: a controlled clinical trial. J Clin Periodontol 2009;36:784-790.

24. Francetti L, Del Fabbro M, Basso M, Testori T, Weinstein R. Enamel matrix proteins in the treatment of intra-bony defects. A prospective 24-month clinical trial. J Clin Periodontol 2004;31:52-59.

25. Francetti L, Trombelli L, Lombardo G, Guida L, Cafiero C, Roccuzzo M, et al.. Evaluation of efficacy of enamel matrix derivative in the treatment of intrabony defects: a 24-month multicenter study. Int J Periodontics Restorative Dent 2005;25:461-473.

26. Jentsch $H$, Purschwitz R. A clinical study evaluating the treatment of supra-alveolar-type defects with access flap surgery with and without an enamel matrix protein derivative: a pilot study. J Clin Periodontol 2008;35:713-718.

27. Okuda K, Momose M, Miyazaki A, Murata M, Yokoyama S, Yonezawa $Y$, et al.. Enamel matrix derivative in the treatment of human intrabony osseous defects. J Periodontol 2000;71:1821-1828.

28. Wachtel H, Schenk G, Böhm S, Weng $D$, Zuhr O, Hürzeler MB. Microsurgical access flap and enamel matrix derivative for the treatment of periodontal intrabony defects: a controlled clinical study. J Clin Periodontol 2003;30:496-504.

29. Zetterström O, Andersson C, Eriksson L, Fredriksson A, Friskopp J, Heden $\mathrm{G}$, et al.. Clinical safety of enamel matrix derivative (EMDOGAIN) in the treatment of periodontal defects. J Clin Periodontol 1997;24:697-704.

30. Esposito M, Grusovin MG, Papanikolaou N, Coulthard P, Worthington HV. Enamel matrix derivative (Emdogain ${ }^{\circledR}$ ) for periodontal tissue regeneration in intrabony defects. Cochrane Database Syst Rev 2009:CD003875

31. Koop R, Merheb J, Quirynen M. Periodontal regeneration with enamel matrix derivative (emd) in reconstructive periodontal therapy. A systematic review. J Periodontol 2012;83:707-720.

32. Esposito M, Coulthard P, Worthington HV, Jokstad A. Quality assessment of randomized controlled trials of oral implants. Int J Oral Maxillofac Implants 2001;16:783-792.

33. Roccuzzo $M$, Bunino $M$, Needleman I, Sanz M. Periodontal plastic surgery for treatment of localized gingival recessions: a systematic review. J Clin Periodontol 2002;29 Suppl 3:178-194; discussion 195196.

34. Mombelli A, Brochut P, Plagnat D, Casagni F, Giannopoulou C. Enamel matrix proteins and systemic antibiotics as adjuncts to non-surgical periodontal treatment: clinical effects. J Clin Periodontol 2005;32:225230.

35. Chambrone D, Pasin IM, Chambrone L, Pannuti CM, Conde MC, Lima LA. Treatment of infrabony defects with or without enamel matrix proteins: a 24-month follow-up randomized pilot study. Quintessence Int 2010;41:125-134.

36. Bhutda $G$, Deo V. Five years clinical results following treatment of human intra-bony defects with an enamel matrix derivative: a randomized controlled trial. Acta Odontol Scand 2013;71:764-770.

37. Bokan I, Bill JS, Schlagenhauf U. Primary flap closure combined with Emdogain alone or Emdogain and Cerasorb in the treatment of intrabony defects. J Clin Periodontol 2006;33:885-893.

38. Silvestri M, Ricci G, Rasperini G, Sartori S, Cattaneo V. Comparison of treatments of infrabony defects with enamel matrix derivative, guided tissue regeneration with a nonresorbable membrane and Widman modified flap. A pilot study. J Clin Periodontol 2000;27:603-610. 
39. Cortellini $\mathrm{P}$, Tonetti MS. Clinical and radiographic outcomes of the modified minimally invasive surgical technique with and without regenerative materials: a randomized controlled trial in intra-bony defects. J Clin Periodontol 2011;38:365-373.

40. Sculean A, Kiss A, Miliauskaite A, Schwarz F, Arweiler NB, Hannig $M$. Ten-year results following treatment of intra-bony defects with enamel matrix proteins and guided tissue regeneration. J Clin Periodontol 2008;35:817-824.

41. De Leonardis D, Paolantonio M. Enamel matrix derivative, alone or associated with a synthetic bone substitute, in the treatment of 1- to 2-wall periodontal defects. J Periodontol 2013;84:444-455.

42. Caton JG. Overview of clinical trials on periodontal regeneration. Ann Periodontol 1997;2:215-222.

43. Garrett S. Periodontal regeneration around natural teeth. Ann Periodontol 1996;1:621-666.

44. Venezia E, Goldstein M, Boyan BD, Schwartz Z. The use of enamel matrix derivative in the treatment of periodontal defects: a literature review and meta-analysis. Crit Rev Oral Biol Med 2004:15:382-402.

45. Cortellini P, Stalpers G, Mollo A, Tonetti MS. Periodontal regeneration versus extraction and prosthetic replacement of teeth severely compromised by attachment loss to the apex: 5 -year results of an ongoing randomized clinical trial. J Clin Periodontol 2011;38:915-924.

46. Carraro JJ, Sznajder N, Alonso CA. Intraoral cancellous bone autografts in the treatment of infrabony pockets. J Clin Periodontol 1976;3:104109.

47. Tonetti MS, Pini-Prato G, Cortellini P. Periodontal regeneration of human intrabony defects. IV. Determinants of healing response. J Periodontol 1993;64:934-940.

48. Killoy WJ. The clinical significance of local chemotherapies. J Clin Periodontol 2002;29 Suppl 2:22-29.

49. Yuan JC, Shyamsunder N, Barao VA, Lee DJ, Sukotjo C. Publication bias in five dental implant journals: an observation from 2005 to 2009. Int J Oral Maxillofac Implants 2011;26:1024-1032.

Received April 8, 2013 Accepted September 13, 2013 